\title{
WATER HYACINTH IN NEW ZEALAND
}

\author{
By D. I. GLUE, Department of Agriculture, Wellington
}

I am going to talk about the water hyacinth problem in New Zealand, and the progress that has been made to date in cleaning up this attractive but extremely undesirable weed.

Water hyacinth's proper name is Eichhornia crassipes. Though not related to the garden hyacinth, the flowers are superficially at least very similar, being violet with a yellow patch on one petal, and it is this resemblance which gives the plant its common name. An acre or so of water hyacinth in flower is a beautiful sight, and in fact the plant's beauty is a major reason why it has become a widely established weed in many countries. The plant itself is most unusual in appearance, and cannot possibly be confused with any other water plant. It has a round glossy leaf, and an inflated petiole or leaf stalk, which, when the plant is small, is almost spherical. As the plant grows larger the leaf stalk elongates and loses its spherical appearance. The largest water hyacinth plants ever measured in New Zealand were growing in the hot spring area at Ohinemutu on Lake Rotorua, where some plants measured more than a yard from base of petiole to tip of leaf.

Water hyacinth is a native of Brazil, but during and since the last century has spread rapidly through most of the tropical countries of the world. It has also become a serious weed in the warmer areas of North America, in Australia, and, to a less degree, in New Zealand.

Why is water hyacinth regarded in so many countries as such a bad weed?

\section{NATURE OF GROWTH}

One of its most characteristic features is that both leaf and petiole are filled with a spongy mass of tissue honey-combed with air cells. This makes the whole plant very buoyant, and it floats high in the water. As it is more than 95 per cent. water, and its demands on its environment are small, it can get the limited amounts of nutrients it requires directly from the water and does not need to have any roots touching the bottom or the bank. This gives it a great advantage over most other water plants, which must get their nourishment direct from soil or mud and, therefore, cannot spread over deep water. Water hyacinth can form a complete bank-to-bank cover in any pond or slow-flowing river no matter how deep. I have seen a pond of about an acre in North Auckland that was so full of water hyacinth that no water was visible anywhere, and the thick mass of vegetation was so buoyant that it would support the weight of a man. It was quite impossible to force a boat through the rubbery mass.

The weed has the faculty of collecting vivid names, particularly in the United States. Names noted in the literature are "Purple Devil Weed", "Lavender Octopus Weed", and "Million Dollar Weed", the last name referring to the expense of eradication.

\section{RATE OF GROWTH}

Water hyacinth nas the distinction of being the fastest spreading water weed in the world. A case is known in Australia where in 3 
months the offspring of a single plant covered an area of 700 sq. yds., simply through vegetative growth not through the growth of seedlings.

\section{EFFECT ON SILTATION RATE}

A major effect of a plug of water hyacinth is to hamper stream flow and cause the deposition of silt. This causes the water level to rise, and ponds or swamps containing water hyacinth tend to increase in size. Further raising of the bottom is caused also by the rapid breakdown and deposition of the very large amounts of organic matter produced by this plant. A dense mass of water hyacinth retains water like a sponge and infested areas are extremely difficult to drain.

\section{EFFECTS ON MICRO-ORGANISMS, PLANTS, BIRDS, AND FISH}

As water hyacinth floats on top, it effectively seals off the water surface from the air and diffusion of oxygen into the water is prevented. Also subaqueous plants tend to be shaded out; therefore less oxygen is liberated into the water by the normal processes of photosynthesis. Sunlight is impeded and the temperature of the water is therefore reduced. The rapid breakdown of the large amounts of organic matter produced by this plant leads to the plentiful liberation of carbon dioxide, and the water becomes more acid and peaty. These changes in water chemistry lead to a heavy mortality among micro-organisms, and the fish population feeding on such micro-organisms also suffers a drastic reduction.

The effects on ducks are equally severe. Though the plant is not only completely unpalatable to ducks, but also competes vigorously with and smothers out a number of the water plants which form the stable feed for ducks in New Zealand, it is known that several infestations here have been started by sportsmen and even by Acclimatisation Societies, under the mistaken impression that they were providing feed and shelter for water fowl.

\section{EFFECTS ON WATER TRAFFIC AND ON STOCK WATERING \\ PLACES}

Water hyacinth forms so dense and rubbery a raft that it is quite impossible to force a boat through it. Stock watering places are also ruined, not only by becoming overgrown with weed, but also by the water becoming peaty and muddy, and therefore less palatable to stock.

The following are a few points about the plant which are of importance in that they affect control.

1. As the plant is a native of the tropics, it is frost tender and its rate of growth tends to fall off with decreasing temperatures. In practice it is likely to be a serious weed only in the warmer districts of the North Island, and it is doubtful if it would survive the winter outdoors in most parts of the South Island.

2. It is a water-loving plant and to survive must be in water or on moist soil.

3. It will not grow in salt water, though it can endure brackish water for a short time.

4. It is popular with aquarium keepers and goldfish fanciers, as the extensive trailing roots are alleged to provide good shelter for fish spawn. 
5. People seeing the plant for the first time are almost invariably attracted by its unusual shape and beautiful flowers. Maoris in particular appear to love it, and in a survey made in 1950 of the incidence of water hyacinth on the northern part of the North Island four out of seven infestations found were on Maori land.

6. It has a high (but undeserved) reputation as a "compost" plant.

\section{HISTORY IN NEW ZEALAND}

The first record of this plant in New Zealand was in the Te Aroha district in 1899. It was known for many years thereafter that there were other infestations, but details were lacking. In 1950 the plant was included in the first schedule of the revised Noxious Weeds Act, despite some opposition from goldfish fanciers and compost clubs, and this automatically meant that there was a $£ 50$ fine for propagating it. About mid1950 A. J. Healy, Assistant Director of the Botany Division, Department of Scientific and Industrial Research, and I carried out a reconnaissance survey to determine the incidence of water hyacinth in the North Auckland, Auckland, and Bay of Plenty districts. At the end of the survey seven infestations were definitely known, and the existence of a large number of small infestations in private gardens was suspected.

The locations of the seven known infestations were:-

Waima, Tautoro, and Matawaia in the Kaikohe district

Lake Rotorua

Lake Muir, near Waiuku

Whakatane

Opotiki

It was found on this survey that the area of the first recorded infestation at Te Aroha had been drained and the water hyacinth eradicated.

Though none of the infestations appeared to be so large as to be beyond economic control, many very large swamps and ponds were seen on the survey, often in close proximity to established infestations, where it appeared obvious that if water hyacinth gained entrance, the cost of eradication would be enormous. It was hoped that by staging an immediate eradication campaign it would be possible to banish the weed entirely from New Zealand and thus obviate at one blow the need for any further expense.

There were three main ways by which control was attempted:-

\section{REMOVAL FROM WATER}

The manual removal of all plants from the water on to dry land was the first way. Often when on dry land the plants were sprayed with hormone weedkillers which helped to break down and destroy them quickly. This technique of manual removal is of most use when employed against smali infestations, for example, goldfish pond size, but can also be of value in the latest stages of clearing up large infestations.

\section{HORMONE WEEDKILLERS}

Water hyacinth is extremely susceptible to hormone weedkillers, in particular to the amines and esters of 2,4-D. If a raft of water hyacinth that is growing over deep water is sprayed, the whole mass soon sinks 
to the bottom and rots. Water hyacinth often grows in a dense association of raupo, rushes, sedges, and water grasses such as Glyceria maxima, and it proved extremely difficult to get a complete cover of water hyacinth by spraying such areas. Owing to the speed of growth, if a few plants were missed, the area rapidly became reinfested. Spraying a dense mass of water hyacinth of differing heights also resulted in the smaller plants being missed, as they tended to be sheltered under the dense foliage of neighbouring taller plants.

One practice which has been frequently employed, and which appears to give very good results, is to spray with $3.61 \mathrm{~b}$. acid equivalent of ethyl ester or butoxy ethanol ester of 2,4-D plus 10 gallons of dieselene plus 200 gallons of water, giving all plants a thorough wetting; then in 2 or 3 weeks giving spot applications to any plants which have survived or missed the previous spraying, with a more concentrated solution, such as $3.61 \mathrm{~b}$. acid equivalent of the same hormone in 80 gallons of dieselene. However, in general very good kills have been experienced both with amine and ester 2,4-D, with and without dieselene.

To make sure of getting a complete cover of water hyacinth plants growing among tall swamp vegetation it was found necessary to work carefully and systematically through swamps yard by yard. This is an extremely laborious and time consuming job and it can readily be imagined that the expense of spraying water hyacinth out of a very large overgrown swamp would be gigantic.

\section{DRAINAGE}

Though drainage has been little used so far, in some cases the most practicable means of control lies in draining the area. This method may have to be more widely used in the future.

\section{REINFESTATION FROM SEED}

After the water hyacinth campaign had been under way for a year or so it became obvious that eradication would be a good deal more difficult than had been previously believed. A small area at Waima only a few square chains in extent, and when the water was only about a foot deep, was repeatedly sprayed and cleared by hand, but each time it was visited numerous tiny water hyacinth plants were observed growing in the mud under the shallow water. It soon became obvious that these were establishing from seed. This was a possibility that had not been allowed for and a discussion of the background may prove of interest.

In its native country, Brazil, water hyacinth is self-fertile, but in a number of countries to which it has spread fertile seed is not set at al or is set only in certain areas. It appears that there are various strains of plants possessing stamens of varying length, and the capacity to set fertile seed is believed to be associated with the length of stamens relative to length of style.

The position in New Zealand, as we now know after some years of trial work, is that in some areas fertile seed is never set. This apparently is the case at Lake Rotorua, where in spite of what appears to be perfect conditions for seeding, no seedlings have yet been found. In other areas, however, fertile seed is set, and seedlings occur in great abundance. This fact has greatly modified our control measures and 
changed our prospects of complete eradication from the practicable to the problematical.

After fertilisation has occurred the stem of the flower bends under water, and seed is shed which falls to the bottom. It can lie dormant there for several years until conditions suitable for germination occur. These conditions depend on a certain degree of light and aeration, and suitable conditions for germination do not usually occur as long as there is a dense layer of water hyacinth on top of the water. This means that in practice seedlings often do not appear until an established infestation has been apparently cleaned up, either by spraying or by dragging, and then there is suddenly a very vigorous reinfestation from seed.

Unlike the adult plants; which obtain all their food direct from the water, seedlings can only develop in contact with mud or soil. Seeds germinate on the bottom, and send out roots which anchor the seedling plants to the bottom. As the plants grow bigger spongy tissue honeycombed with air cells commences to develop in their leaves and petioles, and eventually seedlings become so buoyant that they float to the surface. Camera studies in India have shown that the seedling leaves move gently up and down over a period of about a day, and this prevents seedlings from becoming buried in the mud.

Unfortunately the seeds do not all germinate at the same time, and in India cases have been recorded where seeds kept germinating over a period of 7 years. In the small pond at Waima where seedlings were first noted it is known that no water hyacinth plant has been able to flower for more than $4 \mathrm{x} / 2$ years, but when I visited the area a few weeks ago many hundreds of recently germinated seedlings were lying on the mud covered by a few inches of water. The important point is that while they are under water there is no possibility of tackling them with why hormone weedkillers. Chemicals such as chlorinated benzene might be effective in very small ponds, but no work has yet been done with these materials.

The fact that water hyacinth is setting seed has enormously complicated the control measures. Spraying and dragging must be carried out more frequently and more carefully in order to catch the freshly germinated plants that have just reached the surface. Newly germinated seedlings have been noticed in February, May, and June, and it is possible that germination occurs at all months of the year. In practice, in the areas which have been cleared so far no seeds or seedlings have yet been found, and conversely no area where seedlings have been found has yet been cleared.

The following technique has been worked out as a guide for the tackling of infestations in future.

1. If the area is small, clear it manually, or if it is large, give a complete over-all spray with hormones and follow up with spot applications.

2. Keep a close watch on the area and if any reinfestation occurs, try to determine whether it is due to plants which were missed or to plants germinating from seed.

3. If reinfestation is due to seedlings, keep at them as closely as possible either by manual removal or by spraying after they have floated up to the water surface. At all costs flowering should be prevented, as if seed is allowed to be set, the task of eradication will become endless. 
It may well be that drainage offers the only practicable way of cleaning up areas where large numbers of seedlings keep appearing over a long period of years.

The following is a list of all the water hyacinth infestations at present known:-

Waima and Tautoro, near Kaikohe.

Purua and Waiotu, near Whangarei.

Whakatane (believed almost clear).

Opotiki.

Onehunga.

Lake Rotorua (small infestations only).

Lake Karaka, near Ohinewai.

Tikitiki, Te Puia, and Manutuke, in the Gisborne district.

Tiniroto, near Wairoa.

Wanganui.

Shannon.

In addition there are known to be a considerable number of small infestations in fish ponds and ornamental ponds on private property, particularly in the Auckland district. Though the owners of such ponds may consider the weed can do no harm there, in practice these areas constitute a grave danger, as it is known that a number, if not all, of the infestations in New Zealand have started from just such ponds. If a single plant is taken from such an area, it could start an infestation that could prove ineradicable. It is also known from overseas experience that ducks can carry the seed on their feet, and though there is no record of this method of spread ever having been effective in New Zealand, the danger does exist.

I will end with a request that anyone who knows of an infestation of water hyacinth, whether on private land or anywhere else, should get in touch with the local office of the Department of Agriculture. As long as there is a single water hyacinth plant left alive in New Zealand the prospects of eradication remain uncertain.

\section{DISCUSSION}

Q.-Has water hyacinth been treated from the air?

A.-Most infestations would be difficult to spray from the air, though it could be done. Aerial spraying is done in the U.S.A.

Comment: In Australia water hyacinth occurs in all coastal rivers up the east coast. It has been a major cause of disastrous floods of recent years. It grows in back waters in a dense mat which is lifted by floods and deposited down river to block up waterways.

Q.-Is tigerweed or crocodile weed a potential danger?

A.-These can be controlled with 2,4-D. Unlike water hyacinth they do not roof over a pond.

Q.-What is being done by legal methods to get rid of water hyacinth in small ponds, especially household ponds?

A.-If a noxious weeds inspector sees it in a pond, the owner is asked to destroy it. If a farmer fails to clear it, he can be brought before court. 